\title{
Correction to: Optimizing conditions for labeling of mesenchymal stromal cells (MSCs) with gold nanoparticles: a prerequisite for in vivo tracking of MSCS
}

Philipp Nold ${ }^{1 \dagger}$, Raimo Hartmann ${ }^{2 \dagger}$, Neus Feliu ${ }^{2}$, Karsten Kantner ${ }^{2}$, Mahmoud Gamal $^{2}$, Beatriz Pelaz ${ }^{2}$, Jonas Hühn², Xing Sun ${ }^{2}$, Philipp Jungebluth ${ }^{3}$, Pablo del Pino ${ }^{2}$, Holger Hackstein ${ }^{4}$, Paolo Macchiarini ${ }^{5}$, Wolfgang J. Parak ${ }^{2,6^{*}+}$ and Cornelia Brendel ${ }^{1 *^{*}}$ (i)

\section{Correction to: J Nanobiotechnol (2017) 15:24} https://doi.org/10.1186/s12951-017-0258-5

Figure 5 was published incorrectly in the original publication of the article [1]. The correct version of Fig. 5 is given in this erratum.

The authors apologize for the unfortunate error in the figure during publication of the article. It should also be clarified that some of the solid grey graphs in Fig. 5 are intentionally based on the same data. For 8 different surface makers (CD14, CD73, CD34, CD105, CD19, CD90, CD45, HA-DR) in accordance to the guidelines of the manufacturer a panel of 4 different isotype controls were used, corresponding to 4 different fluorescence channels.
Hospital, Heidelberg, Germany. ${ }^{4}$ Institute for Clinical Immunology and Transfusion Medicine, Justus-Liebig University Giessen, Giessen, Germany. ${ }^{5}$ Laboratory of Bioengineering \& Regenerative Medicine (BioReM), Kazan Federal University, Kazan, Russia. ${ }^{6} \mathrm{CIC}$ Biomagune, San Sebastian, Spain.

Published online: 17 September 2019
The original article can be found online at https://doi.org/10.1186/s1295 1-017-0258-5.

\section{Author details}

1 Department of Hematology, Oncology and Immunology, Philipps University Marburg, Marburg, Germany. ${ }^{2}$ Department of Physics, Philipps-University of Marburg, Marburg, Germany. ${ }^{3}$ Thoraxklinik at Heidelberg University
*Correspondence: wolfgang.parak@physik.uni-marburg.de;

brendelc@staff.uni-marburg.de

${ }^{\dagger}$ Philipp Nold, Raimo Hartmann, Wolfgang J. Parak and Cornelia Brendel

contributed equally to this work

${ }^{1}$ Department of Hematology, Oncology and Immunology, Philipps

University Marburg, Marburg, Germany

2 Department of Physics, Philipps-University of Marburg, Marburg,

Germany

Full list of author information is available at the end of the article (c) The Author(s) 2019. This article is distributed under the terms of the Creative Commons Attribution 4.0 International License (http://creativecommons.org/licenses/by/4.0/), which permits unrestricted use, distribution, and reproduction in any medium, provided you give appropriate credit to the original author(s) and the source, provide a link to the Creative Commons license, and indicate if changes were made. The Creative Commons Public Domain Dedication waiver (http://creativecommons.org/ publicdomain/zero/1.0/) applies to the data made available in this article, unless otherwise stated. 


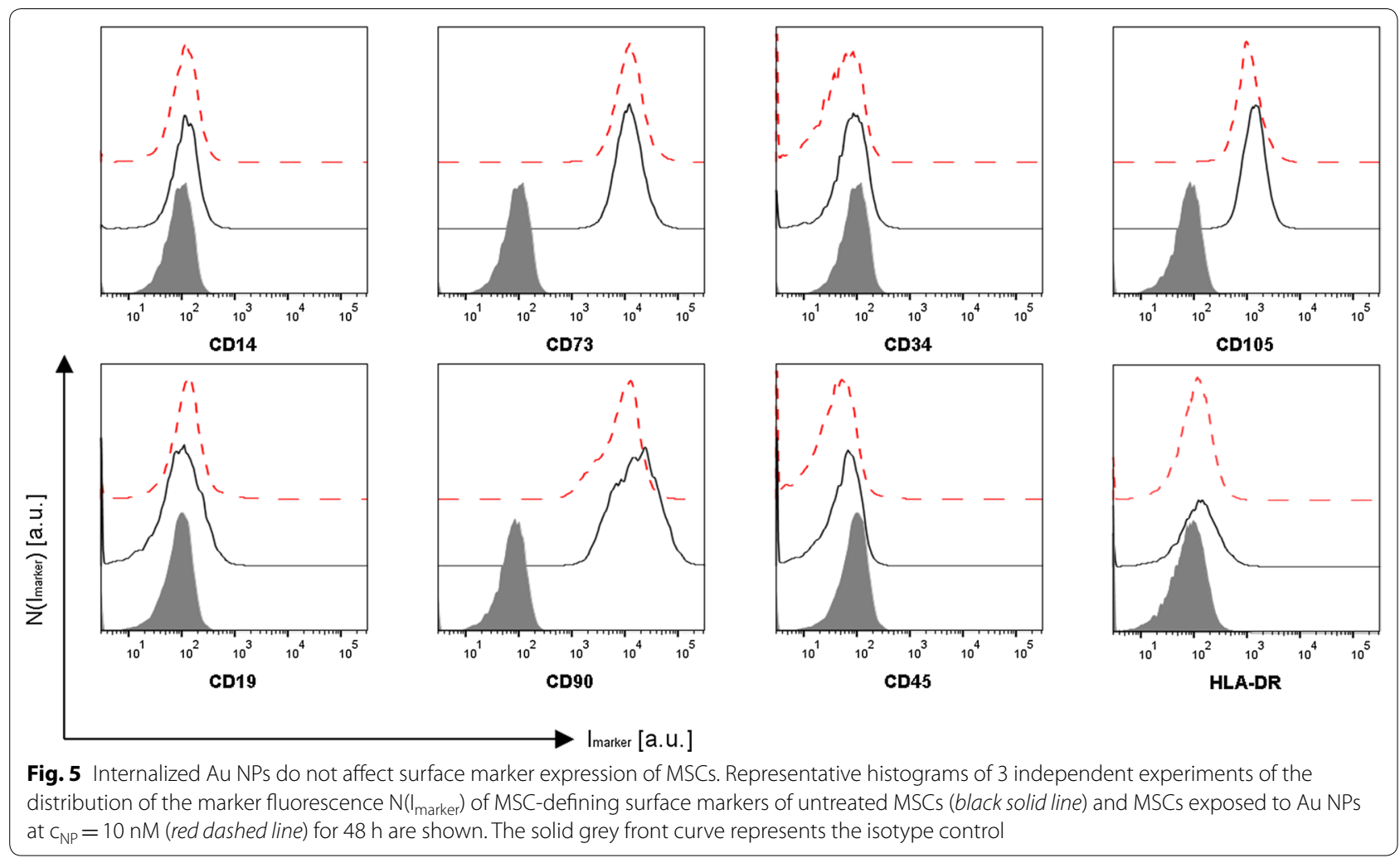

\section{Reference}

1. Nold P, Hartmann R, Feliu N, Kantner K, Gamal M, Pelaz B, Hühn J, Sun X, Jungebluth $\mathrm{P}$, del Pino P, Hackstein H, Macchiarini P, Parak WJ, Brendel C. Optimizing conditions for labeling of mesenchymal stromal cells (MSCs) with gold nanoparticles: a prerequisite for in vivo tracking of MSCs. J

Nanobiotechnol. 2017;15:24. https://doi.org/10.1186/s12951-017-0258-5.

\section{Publisher's Note}

Springer Nature remains neutral with regard to jurisdictional claims in published maps and institutional affiliations.
Ready to submit your research? Choose BMC and benefit from:

- fast, convenient online submission

- thorough peer review by experienced researchers in your field

- rapid publication on acceptance

- support for research data, including large and complex data types

- gold Open Access which fosters wider collaboration and increased citations

- maximum visibility for your research: over $100 \mathrm{M}$ website views per year

At BMC, research is always in progress.

Learn more biomedcentral.com/submissions 